\title{
Demographic, psychological, and environmental factors affecting student's health during the COVID-19 pandemic: on the rocks
}

\author{
Muhammad Khalid Anser ${ }^{1} \cdot$ Muhammad Sharif $^{2} \cdot$ Muhammad Azhar Khan $^{3} \cdot$ Abdelmohsen A. Nassani $^{4}$. \\ Khalid Zaman ${ }^{3} \cdot$ Muhammad Moinuddin Qazi Abro $^{4} \cdot$ Ahmad Kabbani $^{5}$
}

Received: 29 November 2020 / Accepted: 11 February 2021 / Published online: 19 February 2021

(C) The Author(s), under exclusive licence to Springer-Verlag GmbH, DE part of Springer Nature 2021

\begin{abstract}
The novel coronavirus (COVID-19) is spreading exponentially, increasing fear, depression, and other mental health disorders in the general public. Pakistan's economy is suffered mainly by the novel coronavirus. The massive healthcare expenditures bring inadequacy to manage COVID-19. The study explored the effects of coronavirus fear among the students who remain in their homes due to educational institutions' closure. The study results show that female students mostly fear the coronavirus pandemic compared to their male counterparts that negatively impact their health. The "age" of the students and "household size" positively impact students' health, while the student's existing "healthcare profile" is not competitive enough to escape from the deadly coronavirus. The "knowledge" for the coronavirus pandemic and its prevention guidelines is the only solution to contain coronavirus. Simultaneously, "ignorance" is the foremost factor that could be more dangerous to spread coronavirus among the students; besides the COVID-19 pandemic, students and general public health mainly suffered from environmental pollution. The current epidemic also exacerbated environmental concerns among students isolated in their homes, and their outdoor activities are primarily limited. Hence, the student's quality of life is exposed mainly to environmental pollution over time. The "healthcare expenditures" and "government support" both are not competitive enough to control novel coronavirus. Thus, it required more sustainable strategic policies and national unity to controlled coronavirus with firm conviction and provincial synchronization.
\end{abstract}

Keywords COVID-19 Environmental pollution $\cdot$ Student's health $\cdot$ Knowledge $\cdot$ Ignorance $\cdot$ Healthcare expenditures Government support

Responsible editor: Lotfi Aleya

Khalid Zaman

khalid_zaman786@yahoo.com

Abdelmohsen A. Nassani

Nassani@ksu.edu.sa

Muhammad Moinuddin Qazi Abro

mqazi@ksu.edu.sa

1 School of Public Administration, Xi'an University of Architecture and Technology, Xi'an 710000, China

2 School of Economics, Quaid-i-Azam University, Islamabad, Pakistan

3 Department of Economics, University of Haripur, Haripur, Khyber Pakhtunkhwa, Pakistan

4 Department of Management, College of Business Administration, King Saud University, P.O. Box 71115, Riyadh 11587, Saudi Arabia

5 Department of Management, Aleppo University, Aleppo, Syria

\section{Introduction}

The fear of coronavirus is spreading all across the globe that widely damages community health. The students are exposed mainly to the coronavirus pandemic, both mentally and physically. The disruption of their studies and social isolation makes them worst their health profiles; hence, the need for social and healthcare reforms is highly desirable for students to get out of them from misery. Pakistan is among one the countries that effectively handle and monitoring the outbreak of coronavirus. The smart lockdowns, social media campaigns, fundraising, debt resettlement issues, political consensus, and many other programs not limited to charity and direct cash transfer to the needy peoples are the high ranked work for the economy and the welfare of their innocent peoples (Cheema and Riaz 2020; Kalyal 2020; The Tribune Express 2020). The higher education commission of Pakistan introduced many new online educational teaching reforms that 
helped the students and their parent institutes engage them for mutual gain. The following educational-related activities have been organized globally, helping to engage students in their studies and defeat the coronavirus with their intellectual wisdom. For instance, web-based teaching guidelines, educational management and administration (Zhang and Zhang 2020), innovation in high education, online exams, online thesis/projects defense, online entrance, online offering teaching jobs (Strielkowski 2020), redesigned curriculum (The Harvard Gazette 2020), learning at home via interactive apps, live television broadcasts, used Google classroom, Google meets (World Economic Forum 2020), remote learning (The World Bank 2020), distance learning tool kits (OECD 2020), college readiness (NCSL 2020), educational scholarships (Rose 2020), and offered special designed online courses (Sun et al. 2020). These reforms have been mostly viewed in different parts of the world.

The healthcare effects were mostly visible due to coronavirus fear; students' mental health is mainly destroyed. Simultaneously, a number of reforms have been initiated to support students' health across the globe, i.e., the provision of students centered learning environment to express their ideas and share them with their peers to reduce fear and depression (Morgan 2020), increase healthcare expenditures (Rothstein 2020), financial support, direct cash support to the students, easy loan payments schedule to pay back (Sahu 2020), training (Alsafi et al. 2020), continuous learning (Reich et al. 2020), parents working from home and providing a healthy enjoyable environment (Viner et al. 2020), and government social support programs (Cao et al. 2020). These reforms would enable students to get back toward life and adapt to the environment, ensuring a healthy and workable life. Due to the ease of environmental regulations and high political disputes, Pakistan's environmental pollution scenario is alarming due to the cumbersome sustainable environmental reforms' agenda. The current pandemic also exacerbated ecological concerns among the students that quarantine in their homes and their outdoor activities are primarily restricted; hence, their quality of life is exposed mainly to environmental pollution over time.

The study explored the main factors that affect a student's health due to the fear of coronavirus pandemic, as student health is part of community health. Thus, it is used as a "stimulus" factor. Simultaneously, the predictor variables include "knowledge" about the virus, "ignorance" from the virus, "out-of-pocket healthcare expenditures," "social media penetration," "environmental pollution," and "government support" are directly linked with the community health. This study differs from the previous studies from different perspectives; first, community health is represented by students' health isolated in their homes because of school closure and lockdowns. The fear of coronavirus affects both the students' physical and mental health and needs substantial prevention therapies to energies students to come back toward a healthy life. Secondly, knowledge spillovers are used in community health modeling to contained coronavirus, which is considered the best prevention strategy to reduce fear among the general masses. Thirdly, the novel coronavirus is spreading worldwide due to high ignorance found in the broad masses. The main reasons include childishness, lack of knowledge, and overconfidence. Thus, the present study used the variable "ignorance" in community health modeling to observe the student's attitude toward coronavirus pandemic. Fourth, the study used out-of-pocket healthcare expenditures, mass media penetration, environmental pollution, and government support in community health modeling, which would be helpful to assess student's attitude toward the use of protective healthcare measures, social media usage, and thinking about the government's reforms for the needy people and general masses. Finally, the study used few controlled variables, including gender, age, family income, household size, and health profile, which gives the wisdom to understand the students' demographic characteristics to analyze their perceptions and attitudes toward novel coronavirus.

The current study contributed to fill the knowledge gap that exists in the earlier studies in three main domains; firstly, the earlier studies mainly worked on (i) systematic review of assessing mental health about COVID-19 (see Rajkumar 2020; Vindegaard and Benros 2020), (ii) youth mental health affected by the COVID-19 pandemic (Liang et al. 2020), (iii) managing healthcare issues in healthcare professionals (Greenberg et al. 2020), (iv) mental health issues arise in student's parents during COVID-19 (Wu et al. 2020), (v) patients and workforce mental health issues in pandemic crisis, etc. They are less likely to study the qualitative assessment of students primarily affected by COVID-19 because they reside in isolation in-home and study at home to get online lectures. This study filled this gap and comprehensively surveyed all essential aspects of students' mental health issues in the pandemic era. Secondly, the study included the academician response about environmental concerns of COVID-19 measures that affected student's health while asking its possible remedies through open-ended questions - the set of questions designed to get more in-depth knowledge about the vulnerability of coronavirus. Finally, the study included socio-economic, environmental, and demographic factors of students in the regression apparatus to get more insights about the current pandemic and its vulnerability on student's health performance in a country, which gives a value addition in the current literature to get more updates of pandemic effect on public health.

Based on the study's contribution, the following research questions need to be tested, i.e., to what extent healthcare information, health expenditures, media penetration, and government support contain coronavirus pandemic among the general masses, more particularly concerning student's 
health? This question is vital to assess government support and social media campaigns to reduce coronavirus pandemic spread in the general public, including students. The second question is related to the students' household size and health profile, i.e., does a good healthcare profile decrease the incidence of coronavirus diseases in the general public? The healthier students and general public are less likely to get infected with coronavirus disease than the low health profile. Hence, the greater need to use an excellent nutritional diet would help escape from the disease. Finally, does environmental pollution significantly increase health issues that lead to infecting a person with an infectious disease? This question argued that it is the likelihood that environmental pollution gets infected a person in different diseases, including infectious and non-infectious diseases. Thus, it is a greater need to reduce carbon emissions by sustainable instruments.

The following are the objectives of the study, i.e.,

(i) To examine the role of knowledge spillovers in community health modeling to contained novel coronavirus.

(ii) To determine the impact of "ignorance" in spreading novel coronavirus resulting in deteriorating student's health in a country and

(iii) To observe the role of healthcare expenditures, mass media penetration, environmental pollution, and government support to contained novel coronavirus, which impacts students' health in a country.
These objectives required a comprehensive field survey to get the isolated students' responses in their homes and devise prevention strategies for the students to reduce their fear of novel coronavirus.

\section{Material and methods}

The study collected data from many students by inviting students in a Google classroom and approached them with their emails that are isolated in their homes due to the coronavirus pandemic. The self-designed questionnaire was used for this purpose. The universe of the study is the total students that studied in different universities of the country. The homogenous nature of data irrespective of their gender, age, and study disciplines gives leverage to collecting small samples, which provides the desired result. The work is under study in a constraint environment due to complete lockdown in some areas, and partial lockdown in other regions remains a problem to get data from many students. Due to the "stays safe, stay home" policy, we relied on the received data and obtained sound inferences. A total number of 10 university students participated in the study by returning questionnaires by their emails, including, University of Wah, Hazara University, PIDE, Air University, University of Gujrat, AIOU, Arid university, University of Lahore, and Virtual university. The students mainly studied in different departments of their

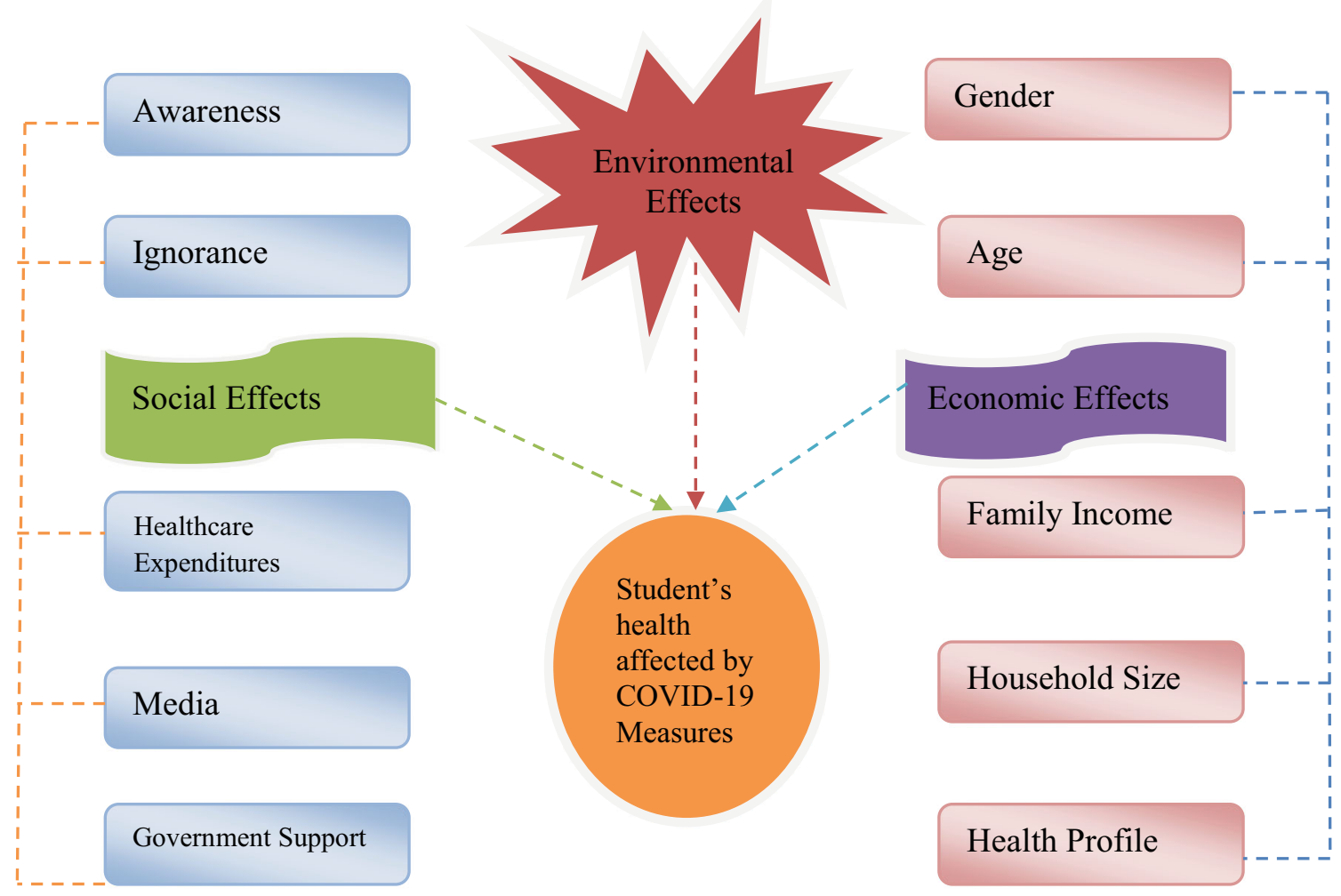

Fig. 1 Research framework of the study. Source: Self-extract 
respective universities, including statistics, education, business management, economics, finance, English, math, and psychology. The level of students is a bachelor's degree to the M.Phil degree program. The study used a self-designed questionnaire that has two parts. The first part is related to the students' demographic characteristics, while the second part consists of 20 items, which represented six variables of the study. The academician asks one open-ended question about environmental concerns of the COVID-19 pandemic on student's health. The student's (SH) is focused on this study and served as a "response variable" mainly affected by the coronavirus pandemic, which consists of 5 items. At the same time, the regressors include (i) awareness/knowledge of coronavirus pandemic (KNOW) among the students consists of
4 items; (ii) ignorance (IGN) about the coronavirus pandemic in the student found with six items; (iii) healthcare expenditures (HE) is used as cost bearing by the students to used hand sanitizers, soaps, protective masks, etc., the single item is used for this purpose; (iv) the use of mass media (MEDIA), including social media, print media, television, etc., to get aware of coronavirus pandemic updates, consisting of 3 items; and finally, (v) Government support (GS) related to coronavirus controlled consist of a single item. The other demographic variables served as control variables, including gender, age of the students (AGE), family income (HHI), household size (HS) (i.e., how many family members in their house), and health profile (HP) (i.e., How many times you get cold and fever in a year?). Table -A in the Supplementary
Fig. 2 Demographics survey. Source: Survey results

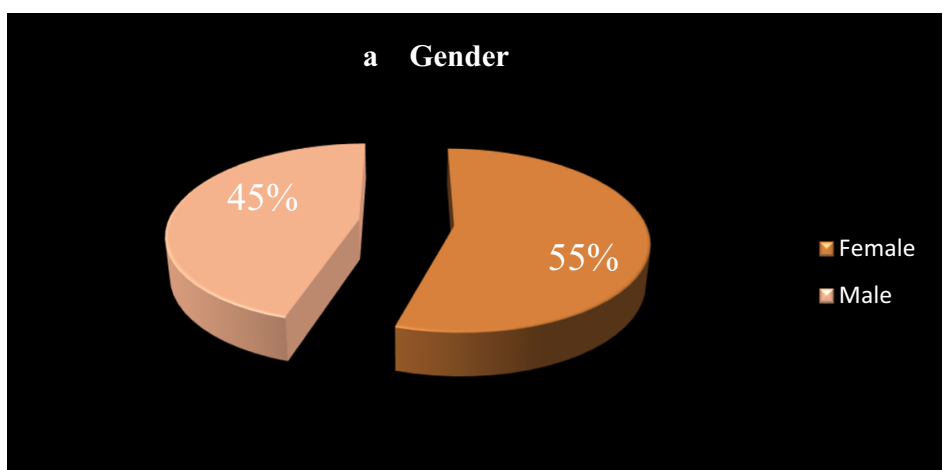

b Respondent's Age

$\square$ Percent

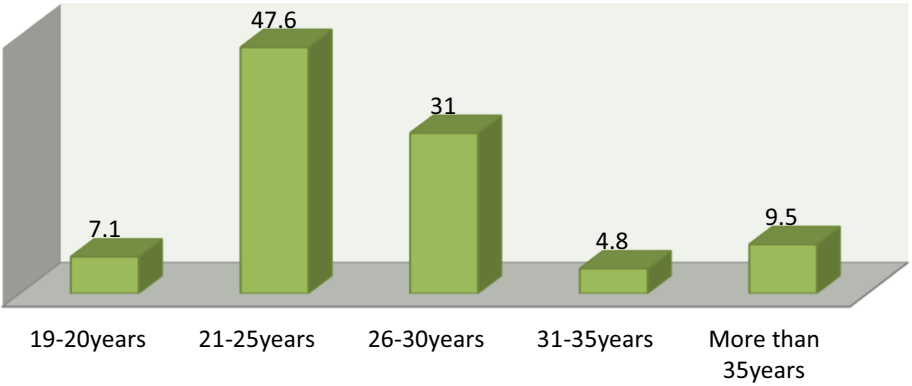

c Family Income

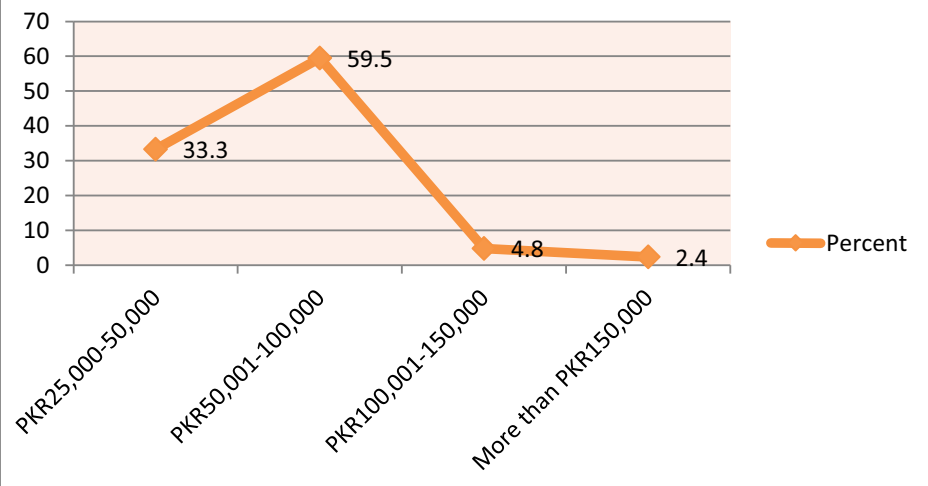


Fig. 3 Descriptive statistics of the variables through the trend line. Source: Survey result

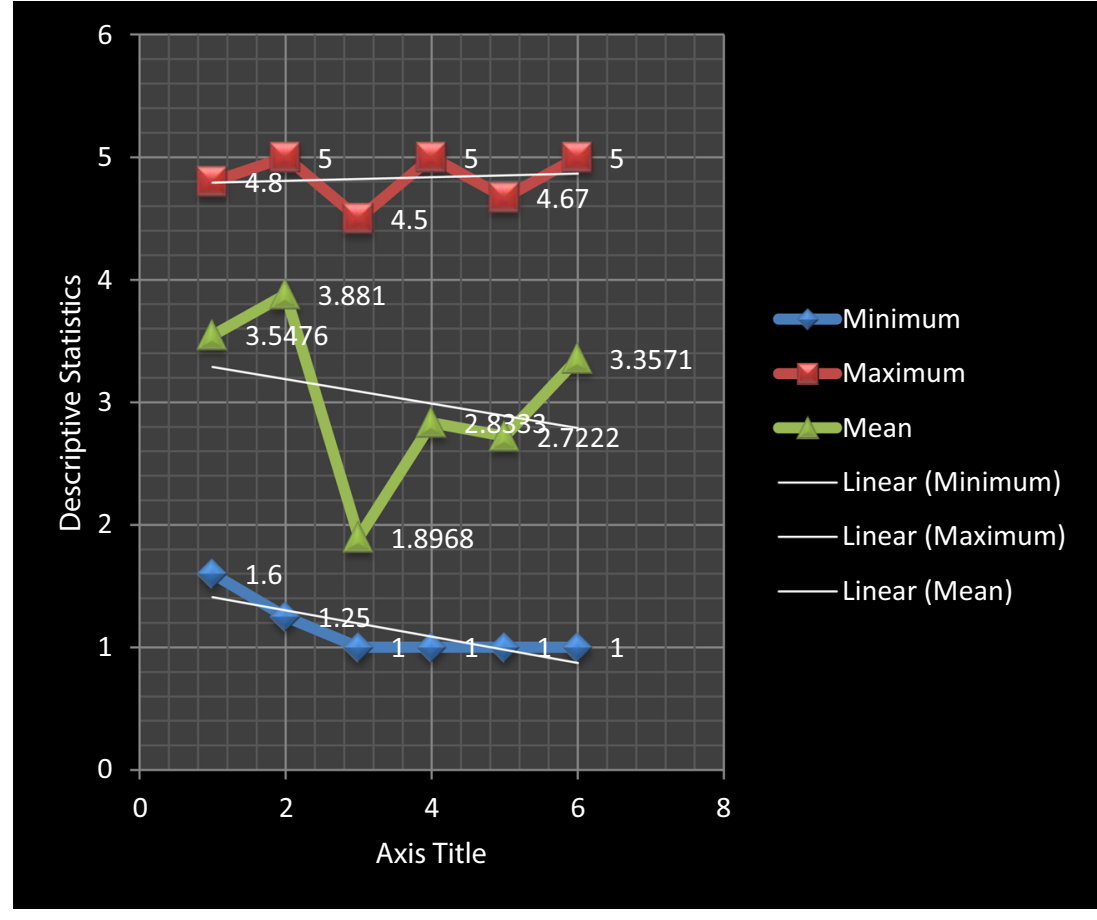

information shows the questionnaire of the study for ready reference.

The convenient sampling and referral-based techniques are used to collect the students' duly filled questionnaires through their emails. The study used a bootstrapped (hierarchal) regression technique to get parameter estimates of the following regression equation, i.e.,

$\left\{\begin{array}{r}\mathrm{SH}=f(\text { KNOW, IGN, HE, MEDIA, GS }) \\ + \\ \mathrm{SH}=f(\text { GENDER, AGE, HHI, HS, HP })\end{array}\right\}$

where SH shows student's health, KNOW shows knowledge, IGN shows ignorance, HE shows healthcare expenditures, MEDIA shows mass media, GS shows government support, " $f$ " shows the functional relationship, GENDER shows students' gender, AGE shows the age of the student, HHI shows family/household income, HS shows the household size, and HP shows health profile of the student.

The bootstrapped regression is used in this study as it has allowed 1000 repetitions of the data to draw the parameter estimates. This technique would be better for obtaining sound inferences. The main crux of the open-ended question is included with the given results. Figure 1 shows the research framework of the study.

The following hypothesis would be analyzed in the study, i.e.,

H1: Awareness/knowledge about coronavirus pandemic will be likely to improve student's health.

$\mathrm{H} 2$ : Ignorance from pandemic may negatively affect student's health.
H3: The higher healthcare expenditures can negatively impact student's health.

H4: Environmental pollution would harm a student's health.

H5: Mass media campaigns about coronavirus pandemic may differentially impact student's health, and

H6: The government support reduced coronavirus cases and improved overall community health.

These hypotheses need to be tested through regression apparatus.

\section{Results and discussion}

The study first analyzed the demographic characteristics of the respondents. Figures 2 a to c show that $45 \%$ of male students participated in the given survey, whereas $55 \%$ of female students participated in the study. The respondent's age mostly falls in between 21 years and 25 years, i.e., $47.6 \%$, followed by $31 \%, 9.5 \%, 7.1 \%$, and $4.8 \%$ of respondents have an age bracket between 26 years to 30 years, more than 35 years, 19 years to 20 years, and 31 years to 35 years respectively. Around $59.5 \%$ of respondents have a family income fall between the PKR50,001 and PKR100,000, whereas 33.3\%, $4.8 \%$, and $2.4 \%$ of respondents have a family income between the range of PKR25,000-PKR50,000; PKR100,001PKR150,000; and more than PKR150,000, respectively.

The survey is based upon 20 questions. In most of the questions asked about the "student's/community health," which is primarily influenced by the coronavirus pandemic, 
Table 1 Bootstrap hierarchical regression

\begin{tabular}{|c|c|c|c|c|c|c|c|}
\hline \multicolumn{2}{|c|}{ Model } & \multirow[t]{3}{*}{$\mathrm{B}$} & \multicolumn{5}{|c|}{ Bootstrap } \\
\hline & & & \multirow[t]{2}{*}{ Bias } & \multirow[t]{2}{*}{ Std. error } & \multirow[t]{2}{*}{ Sig. (2-tailed) } & \multicolumn{2}{|c|}{$\mathrm{BCa} 95 \%$ confidence interval } \\
\hline & & & & & & Lower & Upper \\
\hline \multirow[t]{7}{*}{1} & (Constant) & 1.827 & .138 & .504 & .001 & 1.235 & 2.781 \\
\hline & Gender & -.089 & -.008 & .041 & .022 & -.174 & -.020 \\
\hline & Age & .073 & .000 & .012 & .001 & .057 & .092 \\
\hline & $\mathrm{HHI}$ & -.031 & -.009 & .032 & .355 & -.097 & .006 \\
\hline & HHS & .056 & -.001 & .004 & .001 & .048 & .063 \\
\hline & $\mathrm{HP}$ & -.101 & -.001 & .006 & .001 & -.111 & -.093 \\
\hline & KNOW & .427 & -.025 & .086 & .001 & .269 & .532 \\
\hline \multirow[t]{8}{*}{2} & (Constant) & 1.920 & .142 & .521 & .001 & 1.268 & 2.894 \\
\hline & Gender & -.092 & -.008 & .040 & .022 & -.178 & -.025 \\
\hline & Age & .073 & .000 & .012 & .001 & .057 & .093 \\
\hline & HHI & -.021 & -.009 & .031 & .512 & -.087 & .015 \\
\hline & HHS & .055 & -.001 & .004 & .001 & .047 & .062 \\
\hline & HP & -.101 & -.001 & .006 & .001 & -.111 & -.094 \\
\hline & KNOW & .414 & -.026 & .089 & .001 & .255 & .491 \\
\hline & IGN & -.028 & -.001 & .009 & .001 & -.043 & -.015 \\
\hline \multirow[t]{9}{*}{3} & (Constant) & 1.654 & .173 & .609 & .001 & .888 & 2.773 \\
\hline & Gender & -.107 & -.012 & .031 & .001 & -.177 & -.074 \\
\hline & Age & .046 & -.003 & .019 & .003 & .011 & .075 \\
\hline & HHI & .041 & -.007 & .036 & .301 & -.033 & .091 \\
\hline & HHS & .056 & -.001 & .007 & .001 & .042 & .070 \\
\hline & HP & -.101 & -.001 & .007 & .001 & -.109 & -.094 \\
\hline & KNOW & .418 & -.035 & .117 & .001 & .214 & .518 \\
\hline & IGN & -.081 & -.005 & .013 & .001 & -.097 & -.073 \\
\hline & $\mathrm{HE}$ & .114 & .009 & .019 & .001 & .100 & .161 \\
\hline \multirow[t]{10}{*}{4} & (Constant) & 1.680 & .190 & .587 & .001 & .903 & 2.855 \\
\hline & Gender & -.105 & -.011 & .036 & .001 & -.185 & -.068 \\
\hline & Age & .049 & -.006 & .022 & .075 & .015 & .075 \\
\hline & HHI & .034 & -.006 & .025 & .220 & -.024 & .068 \\
\hline & HHS & .055 & -.001 & .006 & .001 & .043 & .065 \\
\hline & HP & -.101 & -.001 & .006 & .001 & -.110 & -.092 \\
\hline & KNOW & .429 & -.050 & .141 & .001 & .166 & .529 \\
\hline & IGN & -.077 & -.006 & .017 & .001 & -.103 & -.066 \\
\hline & $\mathrm{HE}$ & .117 & .007 & .016 & .001 & .102 & .157 \\
\hline & MED & -.026 & .019 & .048 & .465 & -.070 & .094 \\
\hline \multirow[t]{11}{*}{5} & (Constant) & 1.737 & .186 & .576 & .001 & 1.119 & 2.918 \\
\hline & Gender & -.115 & -.010 & .037 & .001 & -.216 & -.066 \\
\hline & Age & .063 & -.006 & .021 & .001 & .021 & .083 \\
\hline & HHI & .043 & -.006 & .028 & .147 & -.018 & .083 \\
\hline & HHS & .055 & -.001 & .006 & .001 & .043 & .065 \\
\hline & $\mathrm{HP}$ & -.098 & -.001 & .006 & .001 & -.105 & -.091 \\
\hline & KNOW & .450 & -.050 & .142 & .001 & .172 & .584 \\
\hline & IGN & -.091 & -.006 & .015 & .001 & -.115 & -.081 \\
\hline & $\mathrm{HE}$ & .115 & .007 & .016 & .001 & .101 & .156 \\
\hline & MED & -.040 & .019 & .051 & .395 & -.094 & .068 \\
\hline & GS & -.036 & .001 & .011 & .001 & -.049 & -.020 \\
\hline
\end{tabular}

${ }^{\text {a } U n l e s s ~ o t h e r w i s e ~ n o t e d, ~ b o o t s t r a p ~ r e s u l t s ~ a r e ~ b a s e d ~ o n ~} 1000$ stratified bootstrap samples 
Table 2 ANOVA estimates

\begin{tabular}{|c|c|c|c|c|c|c|}
\hline \multicolumn{7}{|c|}{ ANOVA $^{\mathrm{a}}$} \\
\hline \multicolumn{2}{|c|}{ Model } & Sum of squares & df & Mean square & $F$ & Sig. \\
\hline \multirow[t]{3}{*}{1} & Regression & 6.706 & 6 & 1.118 & 2.557 & $.037^{\mathrm{t}}$ \\
\hline & Residual & 15.298 & 35 & .437 & & \\
\hline & Total & 22.005 & 41 & & & \\
\hline \multirow[t]{3}{*}{2} & Regression & 6.719 & 7 & .960 & 2.135 & $.066^{\mathrm{C}}$ \\
\hline & Residual & 15.285 & 34 & .450 & & \\
\hline & Total & 22.005 & 41 & & & \\
\hline \multirow[t]{3}{*}{3} & Regression & 7.574 & 8 & .947 & 2.165 & $.057^{\circ}$ \\
\hline & Residual & 14.430 & 33 & .437 & & \\
\hline & Total & 22.005 & 41 & & & \\
\hline \multirow[t]{3}{*}{4} & Regression & 7.593 & 9 & .844 & 1.873 & $.093^{\circ}$ \\
\hline & Residual & 14.411 & 32 & .450 & & \\
\hline & Total & 22.005 & 41 & & & \\
\hline \multirow[t]{3}{*}{5} & Regression & 7.668 & 10 & .767 & 1.658 & $.136^{\mathrm{f}}$ \\
\hline & Residual & 14.337 & 31 & .462 & & \\
\hline & Total & 22.005 & 41 & & & \\
\hline
\end{tabular}

a shows bootstrap ANOVA value

b shows Model-I estimates

c shows Model-II estimates

d shows Model-III estimates

${ }^{\text {e }}$ shows Model-IV estimates

${ }^{\mathrm{f}}$ shows Model-V estimates

it is evident that most of the respondents are anxious about the coronavirus, and they are keen to improve their physical and mental health to improve their immunity system. Thus, the mean score of the stated variable is more toward the agreed side. The second variable related to the "awareness/knowledge" about the coronavirus among the respondents showed that they are well informed and aware of coronavirus's vulnerability; thus, they highly agreed with the asked statements. The third variable is about "ignorance," as the respondents are keen to take care of themselves and do not ignore the ways to spread the coronavirus. Thus, they asked statements about coronavirus's ignorance; they mostly disagree with the requested statements. The fourth variable is related to the outof-pocket healthcare expenditures, and respondents disagree that sanitizer and other protective instruments are expensive enough, as these measures are necessities in a present condition. They would like to buy them there and used them to protect their selves from the coronavirus. The fifth variable is related to the "penetration of media" in their daily lives, as the respondents are not very much relied on the social media news that is mostly based on out-of-reality. They are capable and mature enough to pick the right information from the right place. Finally, the sixth variable is related to "government support." The respondents are primarily dissatisfied with the government support regarding the charity programs and other reforms that the government or provincial government announced for their needy peoples' welfare.

Figure 3 showed the trend analysis of the variable's description about the cited score in the 5-point Likert scale and indicated that student's health has a mean value of 3.47 with a standard deviation of 0.732 , which exhibits that the respondents are mainly in favor of the asked questions. The knowledge, ignorance, healthcare expenditures, media penetration, and government support have a mean value of $3.881,1.896,2.833,2.722$, and 3.357 , with a standard deviation of $0.785,0.774,1.341,0.915$, and 1.428 , respectively. The higher difference in the mean score is found in the asked questions about the out-ofpocket healthcare expenditures and government support as their standard deviation value is far higher than the rest of the variables. The trend line in the mean value response is mostly dispersed and tends to show some mixed reactions. Thus, the need to use multiple regression analysis is deemed desirable to understand the relationship between the explanatory variables and the explained variable.

Table 3 Model summary

\begin{tabular}{|c|c|c|c|c|c|c|c|c|c|}
\hline \multirow[t]{2}{*}{ Model } & \multirow[t]{2}{*}{$R$} & \multirow{2}{*}{$\begin{array}{l}R- \\
\text { square }\end{array}$} & \multirow{2}{*}{$\begin{array}{l}\text { Adjusted } \\
R \text {-square }\end{array}$} & \multirow{2}{*}{$\begin{array}{l}\text { Std. error of the } \\
\text { estimate }\end{array}$} & \multicolumn{5}{|c|}{ Change statistics } \\
\hline & & & & & $\begin{array}{l}R \text {-square } \\
\text { change }\end{array}$ & $\begin{array}{l}F \\
\text { change }\end{array}$ & df1 & df 2 & $\begin{array}{l}\text { Sig. } F \\
\text { change }\end{array}$ \\
\hline 1 & $.552^{\mathrm{a}}$ & .305 & .186 & .66114 & .305 & 2.557 & 6 & 35 & .037 \\
\hline 2 & $.553^{\mathrm{b}}$ & .305 & .162 & .67050 & .001 & .029 & 1 & 34 & .865 \\
\hline 3 & $.587^{\mathrm{c}}$ & .344 & .185 & .66128 & .039 & 1.955 & 1 & 33 & .171 \\
\hline 4 & $.587^{\mathrm{d}}$ & .345 & .161 & 67109 & .001 & .042 & 1 & 32 & .839 \\
\hline 5 & $.590^{\mathrm{e}}$ & .348 & .138 & .68007 & .003 & .160 & 1 & 31 & .692 \\
\hline \multicolumn{10}{|c|}{ a shows Model-I estimates } \\
\hline \multicolumn{10}{|c|}{ b shows Model-II estimates } \\
\hline \multicolumn{10}{|c|}{ c shows Model-III estimates } \\
\hline \multicolumn{10}{|c|}{${ }^{\mathrm{d}}$ shows Model-IV estimates } \\
\hline e shows & & & & & & & & & \\
\hline
\end{tabular}


The study used hierarchical bootstrap regression to obtain parameter estimates. Table 1 shows that the controlled variable has a significant impact on the dependent variable, i.e., student's health, as females are more likely to fear coronavirus pandemic as compared to their male counterparts; thus, the impact of gender is negative on community health $(-0.089, p<0.022)$. The respondent's age is a matter of understanding mental and physical health, as estimates show that the respondents' age positively influenced students' health, which implies that growing age provides an excellent psychological and physical sense to protect themselves from the coronavirus. The positive effect of household size is found on student's health, increases household size, and has a tight social binding together, and a sense of affiliation; thus, the sense of belonging helps take care of family health through appropriate measures. The healthcare profile of the respondents harms community health, as more and more intensity to get physically ill during the year, there have more chances to get affected through coronavirus. Thus, it is desirable to take care of themselves by using precautionary measures as suggested by the WHO guidelines and the government regulatory bodies (Sohrabi et al. 2020; Agarwal et al. 2020; Hua and Shaw 2020).

The main explanatory variables, including "knowledge," have a positive impact on improving student's health, as more and more awareness and knowledge about coronavirus disease, it is more likely to keep them safe from the coronavirus and eventually increases student's health. The depressing part is the "ignorance" as the more significant number of respondents put aside government instructions and WHO guidelines about how to escape from coronavirus; thus, it negatively affects the community health (see Billauer 2020; Kurian 2020; Thurackal et al. 2020; Sudan and Goswami 2020).
The greater need is to follow the WHO guidelines and government-regulated bodies' instructions to avoid mass gathering and used hand sanitizers and protective masks (Stein 2020; Letchumanan et al. 2020; Kishore and Grover 2020). The out-of-pocket healthcare expenditures positively impact improving student's/community health, as larger the peoples used protective healthcare facilities, the larger they will easy and escape out from the coronavirus. The results are not significant to put a positive impact of media penetration on the students' health. Finally, the government support is not enough to support the needy peoples, thus the high need to announced emergency relief package to the poor people, fundraising, and charity programmers, to give direct cash to the needy peoples to help them in unprecedented times (see, Javed et al. 2020; Malik et al. 2020; Javed 2020).

Table 2 shows the significance of the stated models by ANOVA. The results clearly show that model 1, model 2, and model 3 have significant $F$-statistic values that fall in the $5 \%$ and $10 \%$ confidence interval; thus, the stated models' significance is not problematic. Model 4 and model 5 are statistically insignificant; however, we may not deny the importance of both the models in a given context. Model 4 contained media penetration in the general masses, although the statistical results are not significant; however, its importance is quite visible in Fig. 2, as stated earlier. Model 5 included government support in the community health modeling framework, which is deemed desirable for analyzing the government's role in supporting the country's needy peoples.

Finally, Table 3 shows the model summary of $R$-square changes. The results show that the $R$-square value mainly falls between 0.305 and 0.348 . Although the $R$-square difference is
Table 4 Environmental concerns of COVID-19 pandemic on student's health (open-ended question)

Main
points $\quad$\begin{tabular}{l} 
Response \\
\hline 1 \\
$\begin{array}{l}\text { Environmental pollution is as a danger as the COVID-19 pandemic. Millions of deaths every year } \\
\text { are reported with environmental pollution. The need for sustainable ecological policies is highly } \\
\text { imperative to reduced human death tolls. } \\
\text { Due to the high production and consumption of industrial goods, air pollution exacerbated that } \\
\text { affected people's quality of life. } \\
\text { Air pollution exposure is linked mainly to children's and students' health, not limited to asthma, } \\
\text { mental disorder, cancers, etc. } \\
\text { COVID-19 pandemic directly affects the community members through close socialization, } \\
\text { unhygienic issues, lack of knowledge, high-level ignorance, and many more factors linked to } \\
\text { death. Thus, it is a serious matter to take care of all procedures and guidelines that the govern- } \\
\text { ment spends time with their community members to follow accordingly. Hence, we can contain } \\
\text { the coronavirus efficiently. } \\
\text { Outdoor activities make a person healthy and wealthy, but now the situation is awful, as the } \\
\text { government restricted many of the outdoor activities due to maintaining safety standards during } \\
\text { COVID-19. It negatively affects children's and students' health, singularly as they are } \\
\text { quarantined in their homes (due to disclosures of schools, colleges, and universities) for the last } \\
\text { many months. The feel of fresh air, clean environment, gym exercises, walking, jogging, and } \\
\text { many more other options are essential for their healthy life that can be attached with necessary } \\
\text { SOPs; thus, it can improve the student's health. }\end{array}$ \\
$5 \quad$
\end{tabular}


very negligible and the standard error of the estimate is very close to each other, however, we may safely conclude that the explanatory variables have a significant impact on the response variable as the regression estimates confirmed the significance between the stated variables over the dependent variable broadly fall in the critical regions of 5\% and $10 \%$ level.

The academician asks the open-ended question about environmental concerns of the COVID-19 pandemic on student's health. The main points are reporting in Table 4 for ready reference.

\section{Conclusions and policy implications}

Community health is mostly exposed to the outbreak of the novel coronavirus (COVID-19) that affects cognitive growth led to severe depression, fear, and anxiety among the general masses. The students exposed mainly to the coronavirus outbreak, as their studies have been interrupted, educational institutes have been closed, artificial social media news, a high level of ignorance, and limited convincing therapy make them worse in increasing fear, depression, and mental problems. The study explored the main factors that affect students' health as they are part of the community health. The results show that the respondents' age, household size, and knowledge are the vital factors that support decreasing coronavirus fear and making the students happy and healthy, whereas gender, student's existing healthcare profile, ignorance, healthcare expenditures, and inadequate government support deteriorating community health. The need for providing a clean and green environment for the students makes their lives healthy.

The study found some interesting findings based on the given results; firstly, the fear of coronavirus is more visible in female students than male students that negatively affect their health. Secondly, students' consumption pattern and inclination toward fast foods negatively affect their health, increasing infectious disease incidence because of the low immune system. Thirdly, the students have found a high level of ignorance to adopt the WHO's suggested guidelines to prevent the COVID-19 pandemic, including avoiding massive gatherings and using face masks, which cause a carrier to spread the disease. Finally, government support to contain coronavirus pandemic is not uniform across the cities and regions because of inadequate healthcare resources in a country. Based on the following results, the study proposed the number of possible policy implications in order to escape the students from the fear of coronavirus pandemic, i.e.,

(i) The proper need for COVID-19 counseling is needed among the students to understand the current pandemic threat that may lead to possible death. The current pandemic can be defeated by following the unified government policies, WHO guidelines, and government-regulated monitoring system accordingly.

(ii) Because of the high risk associated with the disclosure of educational institutes and other businesses, it is high time to understand the wake-up call by the international and national regulated bodies to follow their instructions and keep them in mind to escape from the worst scenario.

(iii) The global educational policies have been devised to engage students with their studies through different online platforms. The experience is new for most developed and developing countries where the online educational system is weak and limited. However, it is necessary to get involved in online studies and keep updating their knowledge, which would help minimize the fear of coronavirus and make their life easy and healthy.

(iv) As per the directions of WHO, Pakistan and worldwide abide by the international policies to avoid massive gatherings and keep maintaining them social distancing, which would be helpful to contain coronavirus through knowledge spillovers.

(v) Teachers should learn and be equipped with the latest technologies and keep aware of the coronavirus pandemic and its way to escape from it. Furthermore, teachers should be supportive and kind enough to do proper counseling to the students and keep engaged with them in their studies, so the interaction would increase confidence and a sense of awareness among the students to stay safe in homes.

(vi) There is a high need to make proper exam policies to conduct online quizzes, midterms, and final exams through which students get back serious in their studies and learn and memorize the lectures to get good grades.

(vii) The telecom companies should have to provide cheaper internet rates and high broadband coverage, which would support the students in keeping in touch with their computers and their studies accordingly.

(viii) The higher education commission should give some incentives to the students in the form of free laptop distribution, introduce subsidized internet services, online training programs, online workshops, online degree award ceremony, and many more through which the students could get relaxed and enjoy the happy day.

(ix) The online jobs opportunities, consultation services, and many other windows operations could be started through which the needy students can get some money to pay an educational fee, and the subsidized fee admissions, semester fees, and other dues in schools, colleges, and higher education institutes should be offered and bound the educational institutes to charge lesser fees for distance learning so that the depression could be somehow reduced and community health would be increased accordingly. 
(x) Environmental pollution is another hazardous factor that could damage the students' neurodevelopment function. The need to take healthy diets, regular exercises, walking, jogging, and breathing in the fresh air would reduce the negative environmental externalities. During COVDI-19 measures, these healthful activities have been partially restricted that can be relaxed by attaching specific SOPs to escape them from the coronavirus.

These ten suggested points would help the students make their life healthy and escape from the coronavirus pandemic. The community health can be improved by taking nutritious food, daily indoor exercises, avoid smoking, maintaining social distancing, and used hand sanitizer and soaps whenever getting back home. The provision of some online jobs to needy students is highly required to make some money that can be used to pay subsidized semester fees. The high education commission allows financial institutions to give study loans at zero percent interest rates and give a flexible schedule to return. These unified policies make students could relaxed and mentally healthy.

There is a high time to explore more critical factors associated with the students, which could contain the risk of a second wave of COVID-19 in a country. The use of information and communication technologies as a medium to channelize the information about the pandemic enforces the need to adopt prevention strategies in schools, colleges, universities, and public and private spheres to minimize the risk of infectious diseases. Future studies can be extended to get teachers and administrative staff's feedback to contain the coronavirus pandemic by designing safety standard measures for the student's healthy life. Furthermore, there is a need to improve sustainable healthcare logistics supply chain process to ensure the free flow of healthcare medicines that enable it to give symptomatic treatment to the infected patients on time. Future studies can access the role of sustainable logistics supply chain in pandemic recession to get better insights into the pandemic crisis. The government should have to re-design its policies to achieving environmental sustainability agenda by maintaining an industrial ecology base (Awan 2020a), sustainable innovation strategies (Kanwal and Awan 2021), pollution abatement policies (Awan et al. 2020), and product and process innovation (Awan 2020a, b). All these policies would help improve the healthcare sustainability agenda that is caring to minimize coronavirus disease risk globally.

Supplementary Information The online version contains supplementary material available at https://doi.org/10.1007/s11356-021-12991-x.

Availability of data and materials The primary data is collected from the questionnaire.

Author contributions M.K.A.: conceptualization, methodology, writingreviewing and editing. M.S.: software, formal analysis. M.A.K.: methodology formal analysis. A.A.N.: supervision, resources, software. K.Z.: software, formal analysis, resources. M.M.Q.A.: resources, visualization, formal Analysis. A.K.: data curation, validation.

Acknowledgements Researchers Supporting Project number (RSP2021/87), King Saud University, Riyadh, Saudi Arabia.

\section{Declarations}

Ethics approval All international standards have been adopted and compliance.

Consent to participate All authors equally participated in the study.

Consent to publish All authors allow the publication of the paper.

Competing interests The authors declare no competing interests.

\section{References}

Agarwal A, Nagi N, Chatterjee P, Sarkar S, Mourya D, Sahay RR, Bhatia $\mathrm{R}$ (2020) Guidance for building a dedicated health facility to contain the spread of the 2019 novel coronavirus outbreak. Indian JMed Res 151(2):177-183

Alsafi Z, Abbas AR, Hassan A, Ali MA (2020) The coronavirus pandemic: adaptations in medical education. Int J Surg 78:64-65

Awan U (2020a) Industrial ecology in support of sustainable development goals. In: Leal Filho W, Azul AM, Brandli L, Özuyar PG, Wall $\mathrm{T}$ (eds) Responsible consumption and production. Encyclopedia of the UN Sustainable Development Goals. Springer, Cham. https:// doi.org/10.1007/978-3-319-95726-5 18

Awan U (2020b) Steering for sustainable development goals: a typology of sustainable innovation. In: Leal Filho, W., Azul, A., Brandli, L., Lange Salvia, A., Wall, T. (eds) Industry, innovation and infrastructure. Encyclopedia of the UN Sustainable Development Goals. DOI: https://doi.org/10.1007/978-3-319-71059-4_64-1

Awan U, Kraslawski A, Huiskonen J (2020) Progress from blue to the green world: multilevel governance for pollution prevention planning and sustainability. In: Hussain C (ed) Handbook of environmental materials management. Springer, Cham

Billauer BP (2020) There is nothing to fear-but the fear of coronavirus, itself. Itself.(April 5, 2020). Online available at: https://papers.ssrn. $\mathrm{com} / \mathrm{sol} /$ papers.cfm?abstract_id=3568977 $\left(\right.$ Accessed on $7^{\text {th }}$ May 2020)

Cao W, Fang Z, Hou G, Han M, Xu X, Dong J, Zheng J (2020) The psychological impact of the COVID-19 epidemic on college students in China. Psychiatry Res 287:112934

Cheema HA, Riaz Z (2020) In: Hyder A (ed) The impact of COVID-19 on the mental well-being of individuals. eBook short notes on the economy during the COVID-19 crisis, Vol. 3. Institute of Business Administration, Karachi

Greenberg N, Docherty M, Gnanapragasam S, Wessely S (2020) Managing mental health challenges faced by healthcare workers during covid-19 pandemic. BMJ 368. https://doi.org/10.1136/bmj. $\mathrm{m} 1211$

Hua J, Shaw R (2020) Corona virus (Covid-19)“infodemic" and emerging issues through a data lens: the case of China. Int J Environ Res Public Health 17(7):2309. https://doi.org/10.3390/ijerph17072309

Javed A (2020) Policy review economic impact of coronavirus and revival measures: way forward for Pakistan. Online available at: https://www.researchgate.net/profile/Asif Javed20/publication/ 340477270_Policy_Review_Economic_Impact_of_Coronavirus 
and_Revival_Measures_Way_Forward_for_Pakistan/links/ 5e8c26c7a6fdcca789fbf5ec/Policy-Review-Economic-Impact-ofCoronavirus-and-Revival-Measures-Way-Forward-for-Pakistan.pdf (accessed on 7th May 2020)

Javed B, Sarwer A, Soto EB, Mashwani ZUR (2020) Is Pakistan's response to coronavirus (SARS-CoV-2) adequate to prevent an outbreak? Front Med 7:158

Kalyal H (2020) In: Hyder A (ed) Policing in uncertain times: some global examples and lessons for Pakistan. eBook short notes on the economy during the COVID-19 crisis, Vol. 3. Institute of Business Administration, Karachi

Kanwal N, Awan U (2021) Role of design thinking and biomimicry in leveraging sustainable innovation. In: Leal Filho, W., Azul, A.M., Brandli, L., Lange Salvia, A., Wall, T. (eds) Industry, innovation and infrastructure. Encyclopedia of the UN Sustainable Development Goals. DOI: https://doi.org/10.1007/978-3-31971059-4_86-1

Kishore J, Grover S (2020) Frequently asked questions (FAQs) about coronavirus disease 2019 (Covid-19). Epidemiol Int 5(1):14-21

Kurian NK (2020) Novel Coronavirus (COVID-19) in India. Online available at: https://www.researchgate.net/profile/Noble_K Kurian2/publication/340291694_Novel_Coronavirus_COVID-19_ in_India/links/5e8aba25a6fdcca789f7e677/Novel-CoronavirusCO-VID-19-in-India.pdf (accessed on 7th May 2020)

Letchumanan V, Ab Mutalib NS, Goh BH, Lee LH (2020) Novel coronavirus 2019-nCoV: could this virus become a possible global pandemic. Progress Microbes Molec Biol 3(1):1-6

Liang L, Ren H, Cao R, Hu Y, Qin Z, Li C, Mei S (2020) The effect of COVID-19 on youth mental health. Psychiatry $Q$ 91(3):841-852

Malik YS, Sircar S, Bhat S, Vinodhkumar OR, Tiwari R, Sah R, ..., Dhama K (2020). Emerging coronavirus disease (COVID-19), a pandemic public health emergency with animal linkages: current status update. Online available at: https:/www.preprints.org/ manuscript/202003.0343/v1 (accessed on 7th May 2020)

Morgan H (2020) Best practices for implementing remote learning during a pandemic. Clearing House 93(3):134-140

NCSL (2020) Public education's response to the coronavirus (COVID19) pandemic. Online available at: https://www.ncsl.org/research/ education/public-education-response-to-coronavirus-covid-19.aspx (accessed on 8th May, 2020)

OECD (2020) Quality education for all during Covid-19. Online available at: https://hundred.org/en/collections/quality-education-for-allduring-coronavirus (accessed on 8th May, 2020)

Rajkumar RP (2020) COVID-19 and mental health: a review of the existing literature. Asian J Psychiatr 52:102066

Reich, J., Buttimer, C. J., Fang, A., Hillaire, G., Hirsch, K., Larke, L., ... \& Slama, R. (2020). Remote learning guidance from state education agencies during the COVID-19 pandemic: a first look. Online available at: https://edarxiv.org/437e2 (accessed on 8th May, 2020).

Rose S (2020) Medical student education in the time of COVID-19. Jama $323(21): 2131-2132$

Rothstein MA (2020) The coronavirus pandemic: public health and American values. $J L$ Med Ethics 48(2):1-9

Sahu P (2020) Closure of universities due to coronavirus disease 2019 (COVID-19): impact on education and mental health of students and academic staff. Cureus 12(4):e7541. https://doi.org/10.7759/cureus. 7541

Sohrabi, C., Alsafi, Z., O’Neill, N., Khan, M., Kerwan, A., Al-Jabir, A., ... \& Agha, R. (2020). World Health Organization declares global emergency: a review of the 2019 novel coronavirus (COVID-19). Int J Surg 76, 71-76.

Stein RA (2020) The 2019 coronavirus: learning curves, lessons, and the weakest link. Int J Clin Pract 74(4):e13488

Strielkowski W (2020) COVID-19 pandemic and the digital revolution in academia and higher education. Online available at: https:/www. preprints.org/manuscript/202004.0290/v1 (accessed on 8th May, 2020)

Sudan P, Goswami M (2020) Novel coronavirus (COVID-19)-a critical review. Int J Res Pharmaceut Sci 11(SPL1):43-47

Sun L, Tang Y, Zuo W (2020) Coronavirus pushes education online. Nat Mater 19(6):687-687

The Harvard Gazette (2020) National \& World Affairs: time to fix American education with race-for-space resolve. Online available at: https://news.harvard.edu/gazette/story/2020/04/the-pandemicsimpact-on-education/ (accessed on $8^{\text {th }}$ May, 2020)

The Tribune Express (2020) LIVE: PM stresses need for 'smart lockdown' as national Covid-19 tally surpasses 11,000. Online available at: https://ribune.com.pk/story/2204830/1-trade-activities-setresume-punjab-sindh-covid-19-tally-hits-10513/ (accessed on $8^{\text {th }}$ May, 2020)

The World Bank (2020) World Bank Education and COVID-19. Online available at: https://www.worldbank.org/en/data/interactive/2020/ 03/24/world-bank-education-and-covid-19 (accessed on 8th May, 2020)

Thurackal BJ, Chith EN, Mascarenhas P (2020) The outbreak of novel coronavirus in India: psychological impact. Online available at: https://papers.ssrn.com/sol3/papers.cfm?abstract_id=3562062 (accessed on $7^{\text {th }}$ May 2020)

Vindegaard N, Benros ME (2020) COVID-19 pandemic and mental health consequences: systematic review of the current evidence. Brain Behav Immun 89:531-542

Viner RM, Russell SJ, Croker H, Packer J, Ward J, Stansfield C, Mytton O, Bonell C, Booy R (2020) School closure and management practices during coronavirus outbreaks including COVID-19: a rapid systematic review. Lancet Child Adolesc Health 4(5):397-404

World Economic Forum (2020) 3 ways the coronavirus pandemic could reshape education. Online available at: https://www.weforum.org/ agenda/2020/03/3-ways-coronavirus-is-reshaping-education-andwhat-changes-might-be-here-to-stay/ (accessed on $8^{\text {th }}$ May, 2020)

Wu M, Xu W, Yao Y, Zhang L, Guo L, Fan J, Chen J (2020) Mental health status of students' parents during COVID-19 pandemic and its influence factors. Gen Psychiatry 33(4):e100250

Zhang X (2020) Thoughts on large-scale long-distance web-based teaching in colleges and universities under novel coronavirus pneumonia epidemic: a case of Chengdu University. In 4th International Conference on Culture, Education and Economic Development of Modern Society (ICCESE 2020) (pp. 1222-1225). Atlantis Press

Publisher's note Springer Nature remains neutral with regard to jurisdictional claims in published maps and institutional affiliations. 